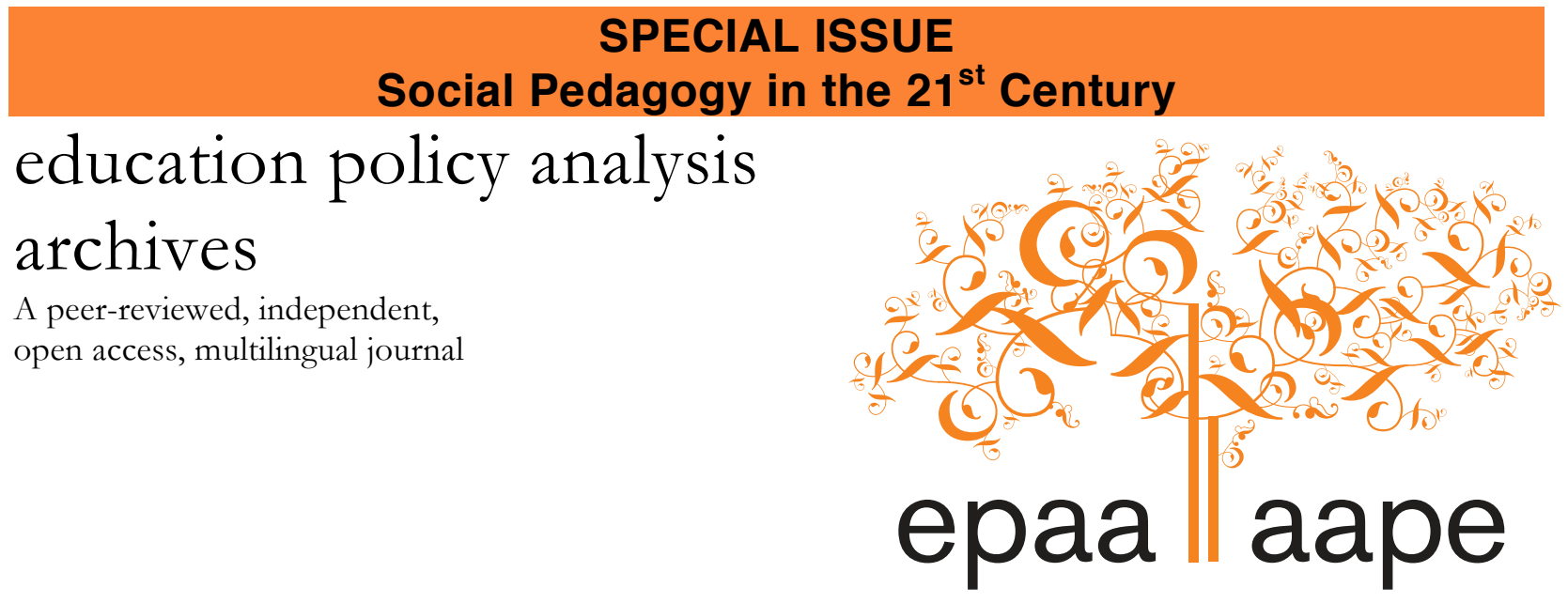

Arizona State University

\title{
Exploring different perspectives of Social Pedagogy: towards a complex and integrated approach
}

\author{
Xavier Úcar \\ Universidad Autónoma de Barcelona \\ Spain
}

Citation: Ucar, X. (2013). Exploring different perspectives of Social Pedagogy: towards a complex and integrated approach. Education Policy Analysis Archives, 21(36). Retrieved [date], from http://epaa.asu.edu/ojs/article/view/1282. This article is part of EPAA/AAPE's Special Issue on Social Pedagogy in the 21st Century, Guest Co-Edited by Dr. Daniel Schugurensky and Michael Silver.

\begin{abstract}
Some characterizations describe social pedagogy as a broad, complex, ambiguous and problematic concept that applies to very different things. This is due to the simplicity of the tools used to approach such a complex area. A change of perspective to interpret social pedagogy as a hybrid and complex subject may transform the alleged deficiencies into strengths and promise. This paper provides elements that enable such a change. To this end, some misunderstandings regarding social pedagogy are presented. These misunderstandings are scenarios and factors that have contributed (1) to the generation of inaccuracies and confusions about what social pedagogy is, could, or should do, and (2) to the projection of an inconsistent and poorly defined image of social pedagogy, i.e. a discipline without method and an ineffective and inefficient practice for solving social problems. The social pedagogy that emerges from the six misunderstandings (cognitive, policy-related, scientist, action-related, normative and social) is complex. From the new perspective, it is more of a hybrid subject (a concept, a discipline and a practice) that is complex, open, dynamic and ever changing.
\end{abstract}

Keywords: pedagogy, social pedagogy, educational theory 


\section{Explorando diferentes perspectivas acerca de la Pedagogía Social: hacia un enfoque complejo e integrado}

Resumen: En la actualidad, algunas caracterizaciones muestran a la pedagogía social como un concepto amplio, complejo, ambiguo y problemático que se aplica a cosas muy diferentes. Esto es debido a la simplicidad de las herramientas utilizadas para tratar con un área tan compleja. Un cambio de perspectiva, que permita interpretar la pedagogía social como un sujeto híbrido y complejo, puede transformar las supuestas deficiencias en fortalezas y posibilidades. Este documento ofrece elementos que posibilitan un cambio de estas características. Para conseguirlo se presenta lo que se caracteriza como "malentendidos" acerca de la pedagogía social. Con esta denominación se pretende recoger toda una serie de escenarios y factores que han contribuido a (1) generar imprecisiones y confusiones acerca de lo que es la pedagogía social, de lo que podría o debería hacer, y (2) proyectar una imagen inconsistente y poco definida de la misma, es decir, una disciplina sin método y una práctica que resulta ineficaz e ineficiente para resolver los problemas sociales. La pedagogía social que emerge de los seis malentendidos (cognitivo, político, científico, de la acción, de la normatividad, y social) es compleja. En la nueva perspectiva, la pedagogía social es entendida como un sujeto híbrido (porque es al mismo tiempo un concepto, una disciplina y una práctica), complejo, abierto, dinámico y cambiante.

Keywords: Pedagogía social; pedagogía; teoría de la educación.

\section{Explorando diferentes perspectivas sobre Pedagogia Social: por uma abordagem complexa e integrada}

Resumo: Atualmente, algumas caracterizações mostram a pedagogia social como um conceito amplo, complexo, ambíguo, e problemático que se aplica a coisas muito diferentes. Isto é devido à simplicidade das ferramentas usadas para aproximar uma área complexa. A mudança de perspectiva para interpretar pedagogia social como um objeto híbrido e complexo pode transformar as alegadas deficiências em pontos fortes e promessa. Este trabalho que fornece elementos permitir tal mudança. Para este fim, alguns mal-entendidos sobre pedagogia social são apresentados. Estes são os cenários e fatores têm que contribuíram (1) a gerar imprecisões e confusões sobre o que é pedagogia social, poderia ou deveria fazer, e (2) a projetar uma imagem inconsistente e mal definidas de pedagogia social, ou seja, a disciplina, sem método, e ineficaz e ineficiente para resolver os problemas sociais. Pedagogia social que emerge das seis Desentendimentos (cognitivo, político, cientista, ação, normativo, e social) é complexa. Na nova perspectiva, é como um objeto híbrido (que é um conceito, uma disciplina, e uma prática) que é complexo, aberto, dinâmico e em constante mutação.

Palavras-chave: Pedagogia social; pedagogia; teoria educacional.

\section{Introduction}

The academic and professional literature on social pedagogy shows many disagreements. Moreover, there are polarized views regarding what social pedagogy is and might be, and how it works. Is social pedagogy a science, a practice or an art, or is it all of these at once? Is there a crosscultural and transdisciplinary (theoretical or methodological) organizational core to social pedagogy or, on the contrary, is it necessary to define as many social pedagogies as there are cultural and disciplinary development contexts? These issues have led the supposed disciplinary unity of social 
pedagogy and its status as a science to be questioned. Some more recent characterizations are claiming that social pedagogy is a broad, complex, ambiguous and problematic concept applied to very different things (Hämäläinen, 2003a; Eriksson \& Markström, 2003; Otto, 2006; Caride, 2007; Lorenz, 2008; Eriksson, 2010; RYWU, 2010; Úcar, 2011).

In my opinion, we should rethink social pedagogy and generate new approaches that are more adjusted to the complexity of current realities. If we change the perspective, we might find that what appear to be flaws, inconsistencies, and contradictions (to the author's eyes) are in fact the results of inadequate interpretation. These apparent deficits lead us to say that social pedagogy is not yet a "mature science" (Rosendal, 2009, p. 202) because it is not supported by any specific theory (Hämäläinen, 2003b; Smith \& White 2007; Brache-Chyrek \& Sünker, 2009) and because it does not have a method of its own (Hämäläinen, 2003a; Coussée et al., 2010). One cannot attempt to understand a complex subject using simple tools because the results will always be incomplete and unsatisfactory.

However, if we think of social pedagogy as a hybrid, interdisciplinary, inter-professional, complex, open, dynamic, changing, alive, and extraordinarily versatile subject, what once seemed to be flaws may end up becoming strengths and possibilities. This is what people and communities are like and this is what social pedagogy ought to be like. Seen this way, it is easy to understand why it appears to be such an attractive approach for dealing with current personal and community problems and situations. The complexity of social pedagogy fits well with the inherent complexity of the social.

This paper aims to propose new elements of reflection and analysis to help with the creation of this new vision. In so doing, I identify six misunderstandings of social pedagogy. These are a number of scenarios and factors that have caused inaccuracies, confusions and polarized perspectives regarding what social pedagogy was, is, and could or should do. Also, these misunderstandings have constructed an image of a contradictory and poorly defined social pedagogy, which changes depending on the contexts of application. From this perspective, social pedagogy lacks a method and, above all, is ineffective and inefficient at solving social problems.

From the analysis of what I call "misunderstandings," a complex social pedagogy emerges. From the new perspective, it is more of a hybrid subject (a concept, a discipline and a practice) that is complex, open, dynamic and ever changing.

\section{The misunderstandings of social pedagogy}

Many of the positions, disagreements, and polarizations raised among authors might be the result of the inaccuracies, misunderstandings, confusion, and traps that have affected social pedagogy throughout its history. A greater understanding of the diversity of approaches underpinning social pedagogy (as a concept, discipline, and practice) can be achieved if these situations (which I encompass with the global term of "misunderstandings") into which authors have fallen are analyzed. In this case, the concept of 'misunderstanding' refers to situations or scenarios in which social pedagogy (whether voluntarily or not) has participated or in which it has been implicated. From such implication, several contradictions, inconsistencies, flaws, and other negative traits have been inferred.

These misunderstandings affect the identity, content, and boundaries of social pedagogy. They act upon its core, thereby confounding what social pedagogy can be. I identified six misunderstandings: (1) the cognitive, related to the method; (2) the political trap, related to the aims and functions of social pedagogy; (3) the misunderstanding of scientificity, which refers to disciplinary conceptualization; (4) the misunderstanding of action and (5) of normativeness, which is 
related with professional actions and their results; and (6) the misunderstanding of the social, which refers to the core and the boundaries of social pedagogy.

These six misunderstandings have affected or are somehow affecting social pedagogy, either in its disciplinary conceptualization or professional practice. It should be noted, however, that some of these have affected social pedagogy due to the discipline to which it belongs (social sciences) or the sector where it is located (pedagogy). The misunderstanding of scientificity exemplifies the former case; the cognitive and normative misunderstandings illustrate the latter.

\section{The cognitive misunderstanding}

The cognitive misunderstanding refers to the conceptual reduction of any kind of pedagogy or education into what children do at school ${ }^{1}$. The pedagogy of the 20 th century focused on schools and individual cognitive learning. Education focused on the teaching-learning process and was organized around content. Although it was posed in educational terms, what happened outside the school was of unclear educational status or had no status at all. These events were more related to charity, surveillance, illness, maladjustment, and social care.

Although it has been clear for years that education cannot be reduced to schools and children and that training and learning are continuous throughout life and produced in very different contexts, it is still a prevailing trend to focus on cognitive education processes ${ }^{2}$.

Most authors agree that the concept of the person is key in any theoretical or practical approach to social pedagogy. Since its inception, what might have distinguished and differentiated social pedagogy from other pedagogies has been how it considers and refers to the person as a whole. Mind, body, feelings, and spirit are integrated in the relationship between the person and others (Petrie, 2001; Kornbeck, 2002; Smith \& White, 2007; Paget et al., 2007; Stephens, 2009; RYWU, 2010). This means that any socio-pedagogical intervention requires an approach that integrates cognition, affect, relationship and action. Personal autonomy - an essential objective of any pedagogy - is an integrated result that is difficult to achieve through fragmented interventions such as the cognitive.

Most authors stress the importance of interpersonal relationships as mediators of sociopedagogical actions, to the extent that these relationships are considered essential to social pedagogy (Kornbeck, 2002). This is characterized as pedagogy of the relationship. The essential feature of social pedagogy is the conscious use of relationships (Bengtsson et al. 2008, p. 9). Research shows that children attach great importance to pedagogical relationships in care (Coussée et al., 2010, p. 793).

Since its very beginnings, social pedagogy has had relative success in its quest to avoid this misunderstanding. Unlike school education, social pedagogy diversifies the places where it operates. The "natural" field of intervention of social pedagogy is people's everyday lives (community, school, family, home, cultural centers, civic centers, shelters, hospitals, streets, and so on). Social pedagogy was not located in one specific institution, so it could divest itself of the cognitive reductionism

\footnotetext{
${ }^{1}$ This has happened throughout Europe but especially in the United Kingdom. In this context, pedagogy has been understood only in its cognitive dimension. Pedagogy has been defined as the science of teaching and learning (Petrie, 2001). So it is historically associated with both training and school. This is why some people say that social pedagogy as a concept is poorly understood and, in the British and American context, it is difficult even for professionals from this field to understand (Hegstrup, 2003). Petrie (2005) refers specifically to the need to extend pedagogy to include other dimensions as well as the cognitive in the concept. ${ }^{2}$ This is a feature of many of the actions of social pedagogy that have been developed in recent years in Latin America. See Úcar 2012.
} 
implemented in schools. However, the price for this lack of constraints was a vague and imprecise status.

\section{The political trap}

Since Nohl characterized them as inspiration and expiration ${ }^{3}$, most authors have taken into account the relationship between social pedagogy and policies. I believe that this proximity to policies has obscured the understanding of what social pedagogy is and the functions it performs. I therefore characterize this misunderstanding as the political trap.

Since Freire (1985), it is clear that all education is political but, unfortunately, not all politics are educational. This means that, more often than is desirable, socio-educational measures have been used to address structural problems that could not be solved by purely educational means. Poverty, exclusion, pain, unemployment, and homelessness are not pedagogical phenomena, but political ones. Pedagogy can do many things, since it includes versatile relational strategies with multiple potentials. In our lives, we can learn almost anything; and therein lays the strength of pedagogy. It is why pedagogy can be such an important political strategy for personal and social change.

Social pedagogy can assist and support the growth and development of children and young adults. It can stimulate, educate, and assist people and communities and raise their awareness of actions that help them to improve as human beings as well as in community settings. Social pedagogy can help, advise, guide, and support them in processes of empowerment that equip them with resources to improve their standard of living. But social pedagogy alone cannot directly improve their standard of living through pedagogical actions. They have to do this themselves. Policies should provide the means and scenarios to do so. Social pedagogy can be one of those means.

This does not mean that social pedagogy cannot be a decisive strategy to influence social conditions through education (Hämäläinen, 2003a; Otto, 2006). In order for this to be the case, social pedagogy's actions and results must be distinguished from those of policies. The key is that social pedagogy and social policies have different temporalities. Social policies must often respond quickly and effectively to problems, even those for which there are no easy solutions or that cannot be solved immediately. Contrarily, education is a slow process that does not cope well with such urgency very efficiently.

Social pedagogy cannot and must not respond to structural problems. This is not its mission or purpose. As Lauritsen rightly pointed out, "the disintegration of society must be recognized as a political and cultural issue rather than scientific or psychological" (2003, p. 98). Or, we could add, a socio-pedagogical one. The problem is not what pedagogy can and cannot do or achieve, but rather what it is being asked to do or what expectations politicians, specialists, and the participants have of it. Thus, I believe it should be stressed that social pedagogy is, first, pedagogy and, although it has a strong political component, it need not perform political functions. The classic maxim of "bread and circuses," for example, has been associated with Social-Cultural Animation programs and activities to emphasize the uselessness and inefficiency of those social pedagogy practices. I believe the confusion or equivalence of these terms (pedagogy and policy) has been used on more than one occasion to show how ineffective social pedagogy is and that it cannot achieve the proposed goals.

I believe these are questions that, in each case, social pedagogy must answer: what can social pedagogy do and what can it not? What belongs and what does not belong to social pedagogy? A clarification of roles and good management of the expectations of all participants in socioeducational action are essential for an accurate evaluation of the results of such actions, as well as of the commitments and responsibilities involved. In order to contribute to the success of policies and

${ }^{3}$ Cit. Hämäläinen, 2003b, p. 143. 
of social pedagogy it is necessary to differentiate what is political from what is socio-pedagogical, and to identify the overlapping areas.

\section{The misunderstanding of scientificity}

This misunderstanding refers to the historical path followed by pedagogy to become a social science at the same level of the others. This issue is probably one of the most influential in the alleged ineffectiveness of social pedagogy. Even more, it has helped to reinforce the lack of academic and social prestige of social pedagogy.

This misunderstanding is simultaneously due to a desire for legitimacy and an inferiority complex among pedagogues. On the one hand, they have always wished for their discipline to enjoy the same status as other social sciences. On the other, they have experienced a complex derived from not being scientifically recognized. Both these issues are linked to the history of pedagogy and the evolution of social sciences.

Brezinka (2002) analyzes the evolution of pedagogy from its beginnings as "a theory of art of education" linked to educational practice (whose value lay in the security that it could provide to educators), until the total shift of the practice towards scientific pedagogy. The heavy price paid for this transformation was the abandonment of practice. Thus, the resulting pedagogy was more scholarly and less practical.

This evolution towards science is explained by the status of art as well as practices in the nineteenth century. It was the century of the emergence and proliferation of social sciences. Being a practice or an art did not help the scientific consideration of pedagogy, since neither one nor the other were taken into account by an academy focused on theory and the scientific method. If pedagogues intended pedagogy to enjoy similar status to that of other social sciences, they needed to establish some distance with respect to practical and artistic activities.

Eighteenth century pedagogy generated high expectations about what its scientific nature could achieve. However, time showed that these expectations were neither met nor led to improvements in educational practice. Scientific pedagogy also failed to reliably predict educational outcomes.

Deprived of a basis on which to ground and build their discourse, the identity and academic production of scientific pedagogy and university pedagogues are both diffuse and poorly connected with educational action and practice. Brezinka (2002) concludes that pejorative judgments of pedagogy probably stem from the disappointment generated by educators and educational processes not meeting all of their expectations in terms of prediction and reliability.

Other authors have pointed out the problems and tensions between scholars and professionals in the field of social pedagogy (Braches-Chyrek \& Sünker, 2009; Rosendal, 2009; Kornbeck, 2009). I believe that this misunderstanding of scientificity is one of the reasons that can explain these problems and tensions.

\section{The misunderstanding of action}

This misunderstanding, related to the practice of social pedagogy, is associated with (1) the diversity of approaches currently used in social pedagogy related to objectives, scope, methodologies, techniques, spaces, and participants; and (2) social pedagogy's difficulty with predicting or assessing the concrete results of its actions.

In social pedagogy, every situation is different and results can be difficult to predict or evaluate. It is therefore better to focus on actions or activities. The misunderstanding of action implies that, during intervention, the objectives to be achieved and the activities or methods to achieve them are often confused with each other. For instance, it is not a matter of "promoting the 
relationships between immigrants and local people," which would be methodological actions developed by social pedagogy, but of getting them to actually relate to each other, i.e., searching for the results of these actions.

The complexity and difficulty of showing learning results when the aim is not only cognitive learning but also comprehensive learning may lead the professional to focus on what can really be controlled, i.e.. the actions and socio-educational methodology that he or she develops. Also, the professional may use allegedly technical language (connected to the scientific misunderstanding) and try to conceal the uncertainty of his or her own actions behind hollow rhetoric. Such rhetoric sets barriers for the pedagogical relationship ${ }^{4}$. The social pedagogue intentionally seeks to connect with the participant through language. Thus the simplest and most relevant expressions will always be the most appropriate. The misunderstanding of action is also related with (1) the complexity of roles developed by social pedagogues in their relationships with participants and (2) with the functions assigned to the institutions for which they work.

Dubet (2006) analyzed changes in social professions as a result of the transformation of our societies in recent decades. He characterized the changes in the relationships professionals have with participants as the decline of the institutional program. Whose emphasis? The term "institutional program" refers to a particular mode of socialization developed by the social professional along with participants. This program assumes that (1) the practitioner is a liaison between universal values and particular individuals, (2) socialization work is a vocation, because it is directly based on values, and (3) socialization is aimed at instilling rules that shape the individual who, in turn, will become simultaneously autonomous and free. It is a type of relationship that teachers, priests or doctors could implement with their students, their parishioners and their patients.

The current decline of this conception of socialization work is a common factor of the actions of all social practitioners. ${ }^{5}$ This decline dislocates the action of social professionals. What is facing a crisis is not only the specific teleos of these actions, but also the meaning that justifies it, the ways in which people embody and project their professional roles, and the forms assumed by praxis.

In this context of professional uncertainty regarding the meaning and content of social praxis, Dubet identifies three logics of action in social professions:

(1) The logic of control: The professional mediates between legal regulations and individuals. These normative references can be political (laws), community (traditions), cultural (customs), etc. From this perspective, the social professional embodies the institution. It permits the assignation of a role to the other, which will then become a student, a patient, an immigrant, or a battered person and must yield the rights, duties, and behaviors associated with that role.

(2) The logic of service: Professionals are experts. They have competencies and techniques that enable them to solve socio-cultural problems; for instance: social support, design of socioeducational projects, development of group dynamics with young people, management of socio-educational community resources, etc. Among other things, this logic enables professionals to serve the poorest communities. It is based on the principle of merit and associated with training and the contract.

\footnotetext{
${ }^{4}$ Trilla expresses these ideas by pointing out that the lack of clarity of pedagogues is a double sin (...) first because most of the solvent content of education is quite intelligible, although some people strive to the contrary, perhaps to suggest rigor and depth (...) second because it is a flagrant contradiction for us as experts to be clumsy in the conveyance of our own knowledge (2005, p. 306).

${ }^{5}$ The surveyed professionals were primary and secondary school teachers, adult trainers, nurses, social workers and mediators.
} 
(3) The logic of relation: Professionals are people who interact with others through certain personal qualities. The relational dimension is based on the principle of recognizing the other as a person.

The combination of these logics shows the span of professional responses in current social complexity. This complexity has left social professionals without transcendental references. They do not embody universal values. The aura of vocation does not accompany them anymore. They do not know whether their actions will generate autonomous and free individuals. As part of the complexities of everyday life in developed societies, it is difficult to find actions that are located in only one of these logics. Although each professional (based on personality, experience, or training) may tend to be oriented towards one of them, these will usually be merged in the daily development of his or her interventions.

\section{The misunderstanding of normativeness}

It has been observed that social pedagogy is a normative science or a normative practice (Hämäläinen, 2003a; Eriksson \& Markström, 2003; Marynowicz-Hetka, 2007; Petrie et al. 2009; Stephens, 2009; Brache-Chyrek \& Sünker, 2009; Van Ewijh, 2010), and it even has been suggested "that without a legislative intention there is no pedagogy" (Trilla, 2005, p. 294) ${ }^{6}$. The misunderstanding of normativeness stems from a confirmation and an impossibility. The former refers to the meaning of pedagogy as a regulatory action. The impossibility is related to two factors that affect such regulations. One refers to how educational standards are shaped and the other to how regulations correlate with the application of norms in terms of education or learning. Both contribute to the image of a dependent and inefficient social pedagogy that cannot achieve what it proposes.

Social pedagogy cannot, by itself, develop the rules needed to appropriately guide socioeducational interventions. Moreover, the application of these rules apparently correlates weakly with the results. In other words, there is no guarantee that the rules applied by the social pedagogue lead to the expected learning outcomes. As Gros says, "there is no direct connection between action and learning" (2008, p. 57). Here arises another connection to the misunderstanding of scientificity. What sense does it make to foster social pedagogy that seeks to say how things should be done but cannot offer guarantees on results? To answer this question, we must analyze how norms are constructed and how social pedagogues apply them.

What distinguishes social pedagogy from other social sciences is that it needs the support of those sciences to construct these rules of action (Hämäläinen, 2003b). Pedagogy and social pedagogy can only produce their norms from the information that is provided by other social sciences. These are what are known as normative syntheses, which are constructed by integrating the evidence provided by those sciences, which help to describe, understand and explain educational phenomena. Research in educational sociology, educational psychology, educational biology, educational anthropology, and other educational sciences provide information on how individuals and groups involve themselves in educational processes.

This is the first step of the process. The second is to report the normative synthesis to participants and to persuade them that it is the best way to achieve the expected learning. In addition, the person must be motivated or encouraged to follow the path signaled by the social pedagogue. This is something that depends solely on the former's motivations, needs, and interests.

Is the normative requirement of pedagogue's lines of action possible when it has to be negotiated with participants? Doubtless, this is the origin of one of social pedagogy's uncertainties.

6 "...I understand normativeness in a broad sense to include (...) principles, criteria, projects, proposals, methods, techniques, materials, tools, etc." (Trilla, 2005, p. 294) 
In this approach, the clash of the technical-professional perspective with that of the humanparticipant is evident.

In my view, it is necessary to distinguish between the professional's territories of action and decision, and those of the participant. The social pedagogue proposes what, from his or her technical perspective, should be done (norm, method, activity, etc.), but ultimately it is the participant who makes the decision on what the appropriate action is. And this is necessarily so because it is a decision about his or her life, over which the subject should ideally be sovereign. This does not mean that in some socio-educational relationships one cannot make decisions for the other, particularly in situations when it is justified by the age of the participants. But even in this case, it is something provisional that leads to the decisional autonomy of the other.

Socio-educational intervention is a process involving two situated entities (social pedagogues and participants), and, as in any interpersonal relationship, the results of intervention, whether successful or not, depend on the involvement and commitment of those agencies. Each brings what they have to offer to the relationship. Social pedagogues bring their expertise and personal and professional experience integrated in pedagogical norms. The participants bring their knowledge of their socio-cultural context and the experience of their lives. They merge at the same level with different roles and areas of action but, at the same time, negotiate when making decisions.

The weak correlation between educational norms and learning outcomes is not due to the ineffectiveness of pedagogy or to its inability to develop norms by itself. It is due to a mechanical and linear interpretation of the relationship, which is implemented in cause-effect terms, i.e., the pedagogue's norm gives rise to a particular effect on the participant. The simplicity of this approach is obvious. However, in social pedagogy, it has been a very difficult misunderstanding to avoid.

Learning outcomes are difficult to predict or plan since they emerge as a "relational property" i.e., as a result of the interaction between the social pedagogue and the participant. Learning outcomes may emerge from this interaction. This is the sense of social normativeness in social pedagogy, which also refers to complexity. An updated normativeness requires the transformation of the classic imperative "it should be" into a probabilistic "it could be if..." or into a practical "what can we do to let it be?"

\section{The misunderstanding of the social}

The social is the reference of social pedagogy. I call this a 'misunderstanding' because a series of considerations has been generated around this concept or scope that conditions the interpretation of social pedagogy. The misunderstanding of the social stems from three ways of understanding it:

1. The social as a stigma. Traditionally, the social as a concept has been related to problems, flaws, or needs. Social services are a good example of this. They were called 'social' because they were targeted at those most in need or who had deficits or problems of any kind. Being a user of these services meant being marked with the stigma of the need or the problem. The social refers to the idea of "sets of insurance and assistive devices to keep social order and social cohesion" (Carballeda, 2002, p. 91; Manuel, 2010).

In recent years, in developed countries, these services began to take shape on the basis of standardization and universalization. In the collective imaginary and in the medium term, this may end up breaking the link between the social and people's deficits, problems or needs. However, this relationship is still a reality today.

\footnotetext{
7 I take this concept from Lahire (2004) who notes that instead of cause and effect, some philosophers prefer to speak of "reciprocal disposition partners" even to refer to physical realities. For instance, "when salt dissolves in water, salt and water are reciprocal partners" (Crane, 1996, p. 9) (2004, p. 83).
} 
Social pedagogy focused on this interpretation of the social may easily be understood as discipline exclusively for people in need and for addressing social problems. This is a social pedagogy whose prime role is "to aid and assist the needy" (Hallstedt \& Hogstrom 2005, p. 14), "to prevent and to alleviate social exclusion and other deprivations" (Hämäläinen, 2003b, p. 147), or event "to eliminate social exclusion" (Kraav 2009, p. 118). The connection between the social trap and the political trap is evident. As I pointed out earlier, social pedagogy cannot eliminate social exclusion nor is this its mission.

If we look at the areas where social pedagogy is acting in different countries, we see that what currently characterizes social pedagogy is not only working with vulnerable people or groups, although this has historically been its field of activity. What defines its purpose today is acting with subjects, whether individual or collective, who live in complex social and cultural contexts, with or without problems.

2. The social as a given, stable and finished entity. A look at recent decades shows irrefutable transformations and changes in our societies and our ways of living and relating. Some authors (Rosendal, 2009; Cousée et al., 2010) have emphasized the need to link pedagogy with the current social reality. According to Manuel (2010), it is necessary to challenge the idea of the social as a given entity, and instead understand it as historical and contingent. According to Poovey $(2002)^{8}$, use of the word "social" as an adjective and as a noun is a recent invention that did not exist before the nineteenth century. This element is related to the misunderstanding of normativeness. If the social is something given and closed, people cannot but adapt or accommodate to the norms shaped by the social. Lash (2003) has clearly denied the latter by saying that, nowadays, the individual has to be a seeker or creator rather than a follower of rules.

3. The social as a distinct entity opposed to the individual. We have to rethink the relationship between the individual and the social. They are not two separate entities but a continuum that is difficult to separate, even though the Western tradition of thought has been stubborn on the matter. Morin's hologramatic principle from his theory of complexity states that an individual is present throughout society in the same way that each individual is in society. In fact, social pedagogy rose to respond to all those dimensions of the person that have not been attended to by traditional pedagogy (Hämäläinen, 2003a). The latter has exclusively focused on cognitive dimensions and has been individually and socially disconnected from people. Beck argues that the current processes of paradoxical socialization (1998, p. 159) indicate individuality as the most advanced form of socialization. He also states that individualization has become the basic social structure of the second modernity (2003, p. 30). The social and the individual are just two terms with which we seek to characterize and understand a reality that is otherwise elusive because of its complexity. Today we understand that these terms offer a simplified view of such reality. The social and the individual are both single and continuous dimensions of the human by which it is very difficult, if not impossible, to discern where one begins and the other ends.

All these misunderstandings were probably due not only to an oversight, but also because of a specific way of seeing the field. The authors and the practitioners sought a well-defined and limited field for social pedagogy. They wanted to delimit and demarcate it. And, obviously, social pedagogy did not fit the canon with which they wanted it to be analyzed. But in the last three decades, the exponential increase in social complexity has provided new frameworks for analysis and

8 Cit. Manuel, 2010. 
interpretation. These have helped to appropriately understand and describe an updated social pedagogy, which is too complex to be grasped with simple schemes of interpretation.

In light of these new approaches, it is possible to reinterpret many of the often contradictory and polarized ideas maintained by authors regarding social pedagogy ${ }^{9}$. I understand social pedagogy, from an interdisciplinary and inter-professional view, to be a hybrid, complex, open, dynamic, changing, alive, and incredibly versatile subject. It may be considered both a science and a practice. When integrated, theory and practice explain social pedagogy, but they cannot do so independently. As a practical science or as a scientific practice, social pedagogy generates new knowledge from its actions and practices. This new knowledge can be applied to generate, once again, specific practices, knowledge and skills in an ever-growing spiral that is always in motion. Therefore, it is difficult to obtain a static picture to define, bind or characterize social pedagogy in a complete and satisfactory way. Social pedagogy is mobile and is continually evolving, just like people, groups and communities.

\section{Conclusions}

Historically, academics and practitioners have considered social pedagogy to be a loosely structured field, without a precise scientific or academic affiliation and with a poorly defined status between science and practice. In social pedagogy, it was once normal for authors to express diverse positions and polarized views. In this paper, I have discussed some of the misunderstandings that are connected to these visions. I have also argued that it is possible to have a complex vision of social pedagogy.

The complexity of social pedagogy is derived from the multiplicity of the spaces and times in which individuals, groups, and communities develop their actions. Also, unlike traditional pedagogy and especially scholarly pedagogy, it considers the person whole, without separating knowledge, feelings, and actions. All these dimensions of the person are activated and developed by their relationships with others. So relationships that occur in people's everyday lives are, at the same time, vehicles, contexts, and contents of socio-pedagogical actions.

The so-called "political trap" has shown the inherent risk of the comparison between social pedagogy and politics, or the instrumentalization of the former by the latter. From this point derives another source of complexity in social pedagogy: how to balance its actions in different dimensions (social, cultural, technical, etc.) and prevent the political dimension from engulfing all of the others.

The issue of the scientificity of the social sciences in general and in particular of social pedagogy has led us to wonder about the status and characteristics of socio-pedagogical actions. Specifically, we have to consider the interdependence between theory and practice (a central theme in social pedagogy) and the complementary characteristics as a technical and artistic endeavor. We have also revealed a plausible explanation for the gap between academic and practical aspects in the field of social pedagogy.

The complexity of social pedagogy has been analyzed through some of the problems arising from the diversity of objectives, scope, methodologies, techniques, spaces, and participants that can configure this discipline, and also by the difficulty of predicting the results of actions. We have related this difficulty with a way of understanding normative aspects in social pedagogy. If the results of actions are unpredictable, it is because they are not the result of a linear and mechanical understanding of the socio-pedagogical relation. The educational standards are not prescribed in a single direction but rather emerge as "a relational property" as a result of an ad hoc construction, situated and agreed between the social pedagogue and the participant.

The misunderstanding of social issues is probably due to the vast number of transformations

${ }^{9}$ For an analysis of authors' polarized views of social pedagogy, see Úcar, 2011. 
in our societies in recent decades, which have introduced greater complexity to the way we understand, conceptualize, and act in social pedagogy. The evolution of the different ways of understanding the concept - (1) from the social as a stigma to the social as a relation (physical and virtual), (2) the social as a dynamic, and, (3) social and individual concepts understood as continuous or integrated elements and not as closed and exclusive) - represented an extension not just for the fields of action, but also in the different ways of practicing social pedagogy. In the Spanish framework, for instance, the evolution of the concept of social pedagogy has been illustrated by pointing out how we are now also doing it in the field of freedom, even though we have historically been working in the field of needs (Trilla, 1992) ${ }^{10}$. This new perspective of social pedagogy fits better with the current complexities of our societies. It may also help explain some of the polarizations, ambiguities, and inaccuracies expressed by the authors in relation to specific aspects or interpretations of social pedagogy.

Social pedagogy has its own method but it emerges in every pedagogical encounter. Whether the actions of social pedagogues are placed in the logic of control, the logic of service, the logic of relationship (Dubet, 2006), or in an overlap between them, socio-pedagogical actions operate in unpredictable and unrepeatable socio-cultural contexts. Unpredictability and uniqueness open the door to the creativity of agents and to the constant search for new paths, new questions, and new answers. Such an approach transcends the realm of the purely technical or the purely scientific. I contend that both technique and science are necessary yet insufficient to provide appropriate responses to the complexity of human relationships. Perhaps, as pointed out by Morin, we are beginning to see that the next step to science and technology is art. Perhaps, ultimately, we need to return to the classical conception of the art of education.

\section{References}

Beck, U. (1998). La sociedad del riesgo. [The risc society] Barcelona: Paidós.

Beck, U. \& Beck-Gernsheim, E. (2003). La individualización. El individualismo institucionalizado y sus consecuencias sociales y politicas. [Individualization. Institutionalized individualism and its social and political consequences]. Barcelona: Paidós.

Braches-Chyrek, R. \& Süncker, H. (2009). “Will Social pedagogy disappear in Germany?”. In J. Kornbeck and N. Rosendal Jensen (Eds.), The diversity of Social Pedagogy in Europe. Studies in Comparative Social Pedagogies and International Social Work and Social Policy. (pp. 15-21). Bremen: Europäischer Hochschulverlag GmbH \& Co. KG.

Brezinka, W. (2002). Sobre las esperanzas del educador y la imperfección de la pedagogía [About the hopes of the educator and the imperfection of pedagogy]. Revista española de Pedagogia, 223, $399-415$.

Caride, J.A. (2007). La pedagogía social ante el proceso de convergencia europea de la educación superior. [Social pedagogy to the process of European convergence of higher education]. Pedagogía Social. Revista interuniversitaria, 14, 11-31.

Carballeda, A.J. (2002). La intervención en lo social. Exclusión e integración en los nuevos escenarios sociales. [The intervention in the social. Exclusion and integration into new social settings]. Buenos Aires: Paidos.

\footnotetext{
10 An example of this is socio-cultural animation. Kornbeck and Rosendal Jensen $(2011,2012)$ have characterized the whole life story of the human being as an individual that is susceptible to socio-pedagogical work.
} 
Coussée, F., Bradt, L., Roose, R. \& Bouverne-De Bie, M. (2010). "The emerging social, pedagogical paradigma in UK Child and Youth Care: Deus ex machina or walking the beaten path", British Journal of Social Work, 40, 789-805.

Dubet, F. (2006). El declive de la institución. Profesiones, sujetos e individuos en la modernidad. [The decline of the institution. Professions, and individuals subject in modernity] Barcelona: Gedisa.

Eriksson, L. (2010). Community development and social pedagogy: traditions for understanding mobilization for collective self-development, Community Development Journal, 46 (4), 403-420. doi: $10.1093 /$ cdj/bsq008.

Eriksson, L. \& Markström, A.M. (2003). "Interpreting the concept of social pedagogy". In A. Gustavsson; H. Hermansson, and J. Hämäläinen, (Eds.) Perspectives and theory in social pedagogy. (pp. 9-23). Goteborg: Bokförlaget Daidalos A.B.

Freire, P. (1970). Pedagogía del oprimido. [Pedagogy of the Oppressed]. Madrid: Siglo XXI.

Gros, B. (2008). Aprendizajes, conexiones y artefactos. La producción colaborativa del conocimiento. [Learning, connections and artifacts. Collaborative knowledge production]. Barcelona: Gedisa.

Hallstedt, P. \& Högström, M. (2005). The recontextualisation of social pedagogy. A study of three curricula in the Netherlands, Norway and Ireland. Retrieved from http://dspace.mah.se:8080/bitstream/2043/7231/1/Hallstedt_Hoegstroem_manus.pdf

Hämäläinen, J. (2003a). The concept of social pedagogy in the field of social work. Journal of Social Work, 3, 69-80.

Hämäläinen, J. (2003b). "Developing social pedagogy as an academic discipline In A. Gustavsson; H. Hermansson, and J. Hämäläinen, (Eds.) Perspectives and theory in social pedagogy. (pp. 133154). Goteborg: Bokförlaget Daidalos A.B.

Hegstrup, S. (2003). "Tendencies and trends in social pedagogyin Denmark at the turn of the millennium”. In A. Gustavsson; H. Hermansson, and J. Hämäläinen, (Eds.) Perspectives and theory in social pedagogy. (pp 72-83). Goteborg: Bokförlaget Daidalos A.B.

Kornbeck, J. (2002). Reflections on the Exportability of Social Pedagogy and its Possible Limits, Social Work in Europe, 9 (2), 37-49.

Kornbeck, J. (2009). "Important but widely misunderstood: the problem of defining social pedagogy in Europe”. In J. Kornbeck and N. Rosendal Jensen (Eds.), The diversity of Social Pedagogy in Europe. Studies in Comparative Social Pedagogies and International Social Work and Social Policy, Bremen, Europäischer Hochschulverlag GmbH \& Co. KG.

Kornbeck, J. and Rosendal Jensen, N. (Eds.) (2011). (Eds.) Social Pedagogy for the entire human lifespan. Vol I. Bremen, Europäischer Hochschulverlag GmbH \& Co. KG.

Kornbeck, J. and Rosendal Jensen, N. (Eds.) (2012). (Eds.) Social Pedagogy for the entire human lifespan. $V$ ol II. Bremen, Europäischer Hochschulverlag GmbH \& Co. KG.

Kraav, I. (2003). "Development perspectivas of social pedagogy in Estonia”. In A. Gustavsson; H. Hermansson, and J. Hämäläinen, (Eds.) Perspectives and theory in social pedagogy. (pp. 117-133). Goteborg: Bokförlaget Daidalos A.B.

Lahire, B. (2004). El hombre plural. Los resortes de la acción. [Man plural. The springs of action]. Barcelona: Edicions Bellaterra.

Lash, S. (2003). "Individualización a la manera no lineal". [Individualization of the nonlinearly]. In U. Beck \& E. Beck-Gernsheim, La individualización. El individualismo institucionalizado y sus consecuencias sociales y politicas. [Individualization. Institutionalized individualism and its social and political consequences]. (pp. 9-19). Barcelona: Paidós.

Lauritsen, J. (2003). "In between post structuralism and phenomenology? In A. Gustavsson; H. Hermansson, and J. Hämäläinen (Eds.), Perspectives and theory in social pedagogy. (pp. 83-100). Goteborg: Bokförlaget Daidalos A.B. 
Lorenz, W. (2008). "Paradigms and politics: understanding methods paradigms in an historical context: the case of social pedagogy". British Journal of Social Work, 38, 625-644.

Manuel, J.T. (2010). Rethinking the Social in Social Studies, The Councilor: The Journal of the Illinois Council for the Social Studies, 71 (2), 1-11.

Marynowicz-Hetka, E. (2007). Towards the transversalism of social pedagogy, Social work \& society. 5, 53-68.

Morin, E. (1993). El método. La naturaleza de la naturaleza. [The method. The nature of nature]. Madrid: Cátedra.

Otto, H. (2006). "Social pedagogy and social work: evolution and perspectivas?". In Proceedings of the 1. I Congresso Internacional de Pedagogia Social, São Paulo (SP). Retrieved from http://www.proceedings.scielo.br/scielo.php?script=sci_arttext\&pid=MSC00000000920060 $\underline{00100017 \& \operatorname{lng}=\text { en\&nrm }=\text { iso }}$

Paget, B., Eagle, G. \& Citarella, V. (2007). Social pedagogy and the young people's workforce. A report for the Department for children, Schools and families. Retrieved from http://www.cpea.co.uk/download.php?file=social pedagogy and young people.pdf.

Petrie, P. (2001). The potential of pedagogy/education for work in the children's sector in the UK, Social work in Europe, 8 (3), 23-25.

Petrie, P. (2005). "Extending Pedagogy", Journal of education for teaching. 31 (4), 293-296.

Regional Youth Work Unit-North-East (RYWU) (2010). "A study on the understanding of social pedagogy and its potential implications for youth work practice and training". University of Sunderland. Centre for Children, Young people and families. Retrieved from http://www.rywu.org.uk/wp-content/uploads/2010/05/Social-PedagogyReport.pdf

Rosendal, N. (2009). "Will Social pedagogy become an academic discipline in Denmark". In J. Kornbeck and N. Rosendal Jensen (Eds.), The diversity of Social Pedagogy in Europe. Studies in Comparative Social Pedagogies and International Social Work and Social Policy, (pp. 189-210). Bremen, Europäischer Hochschulverlag GmbH \& Co. KG.

Smith, M. \& Whyte, B. (2007). Social education and social pedagogy: reclaiming a Scottish tradition in social work, European Journal of Social Work, 11 (1), 15-28.

Stephens, P. (2009). "The nature of social pedagogy: an excursion in Norwegian territory", Child \& family social work, 14, 343-351.

Trilla, J. (1992). "La educación no formal. Definición, conceptos básicos y ámbitos de aplicación" [Non-formal education. Definition, basic concepts and application areas]. In J. Sarramona (Ed.), La educación no formal. [Non-formal education]. (pp. 9-51). Barcelona, Ceac.

Trilla, J. (2005). "Hacer pedagogía hoy". [Make pedagogy today]. In Ruiz Berrio, J. (Edit), Pedagogía y educación ante el siglo XXI. [Pedagogy and education to the XXI century]. (pp. 287-310). Madrid: Departamento de teoría e historia de la educación.

Úcar, X. (2011). "Social pedagogy: beyond disciplinary traditions and cultural contexts?”. In J. Kornbeck and N. Rosendal Jensen (Eds.) Social Pedagogy for the entire human lifespan. Vol I, (pp.125-156). Bremen, Europäischer Hochschulverlag GmbH \& Co. KG.

Úcar, X. (2012) "Social pedagogy in Latin America and Europe: looking for new answers to old qüestions". In J. Kornbeck; N. Rosendal Jensen (Eds.) Social Pedagogy for the entire human lifespan. Vol II, (pp.166-201). Bremen, Europäischer Hochschulverlag GmbH \& Co. KG.

Van Ewijk, H. (2010). Positioning Social Work in a Socially Sensitive Society, Social Work \& Society, 8. Retrieved from http://www.socwork.net/2010/1/vanewijk. 


\title{
About the Author
}

\author{
Xavier Úcar \\ Dpt. Pedagogia Sistemática y Social. Universidad Autónoma de Barcelona. Spain \\ Email: Xavier.ucar@uab.cat \\ Xavier Úcar is Full Professor of Social Pedagogy. He specializes in Social Pedagogy and Design and \\ the Evaluation of Socio-cultural Animation Programs and Community Development Programs. He \\ is President of the Iberoamerican Society of Social Pedagogy (SIPS). He is co-director of the \\ Collection of books on "Community Action and Social-Educative Action" by Graó Publishers. He has \\ written more than 100 publications including books, book chapters and journal articles. \\ http://uab.academia.edu/XavierUcar
}

\section{About the Guest Co-Editors}

\section{Daniel Schugurensky}

Arizona State University

Email: dschugur@asu.edu

Daniel Schugurensky is Full professor at Arizona State University, where he has joint appointment in the School of Public Affairs and the School of Social Transformation. He is the Head of the Area of Justice and Social Inquiry, and the coordinator of the Masters program in social and cultural pedagogy. He has written extensively on youth and adult education, community development and participatory democracy. Among his recent authored and coedited books are Ruptures, continuities and re-learning: The political participation of Latin Americans in Canada (Transformative Learning Centre, University of Toronto, 2006), Four in Ten: Spanish-Speaking Youth and Early School Leaving in Toronto (LARED, 2009), Learning citizenship by practicing democracy: international initiatives and perspectives (Cambridge Scholarly Press, 2010), Paulo Freire (Continuum, 2011), and Volunteer work, informal learning and social action (Sense 2013).

\section{Michael Silver}

Arizona State University

Email: Michael.Silver@asu.edu

Michael Silver is a Research Fellow at the National Center on Education and the Economy and the Center for the Future of Arizona. As a Doctoral Student in Educational Policy and Evaluation, his research focuses on policies affecting educational equity and issues of social justice - particularly those related to historically vulnerable, minority populations. 

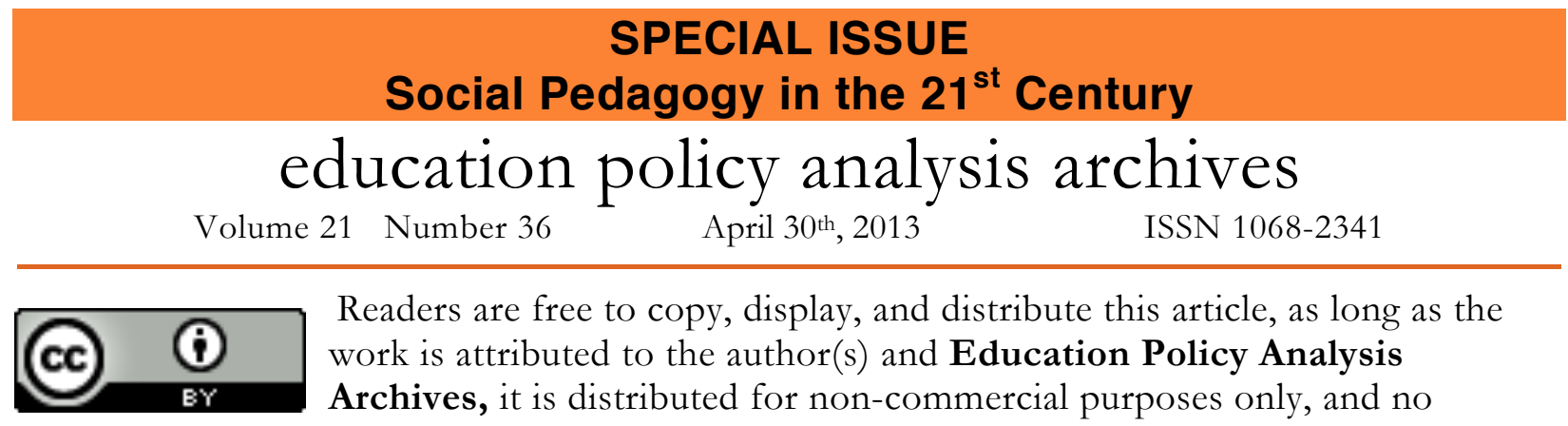

Readers are free to copy, display, and distribute this article, as long as the work is attributed to the author(s) and Education Policy Analysis

Archives, it is distributed for non-commercial purposes only, and no alteration or transformation is made in the work. More details of this Creative Commons license are available at http://creativecommons.org/licenses/by-nc-sa/3.0/. All other uses must be approved by the author(s) or EPAA. EPAA is published by the Mary Lou Fulton Institute and Graduate School of Education at Arizona State University Articles are indexed in CIRC (Clasificación Integrada de Revistas Científicas, Spain), DIALNET (Spain), Directory of Open Access Journals, EBSCO Education Research Complete, ERIC, Education Full Text (H.W. Wilson), QUALIS A2 (Brazil), SCImago Journal Rank; SCOPUS, SOCOLAR (China).

Please contribute commentaries at http://epaa.info/wordpress/ and send errata notes to Gustavo E. Fischman fischman@asu.edu

Join EPAA's Facebook community at https://www.facebook.com/EPAAAAPE and Twitter feed@epaa_aape. 


\section{education policy analysis archives editorial board}

Editor Gustavo E. Fischman (Arizona State University)

Associate Editors: David R. Garcia (Arizona State University), Stephen Lawton (Arizona State University)

Rick Mintrop, (University of California, Berkeley) Jeanne M. Powers (Arizona State University)

Jessica Allen University of Colorado, Boulder

Gary Anderson New York University

Michael W. Apple University of Wisconsin, Madison

Angela Arzubiaga Arizona State University

David C. Berliner Arizona State University

Robert Bickel Marshall University

Henry Braun Boston College

Eric Camburn University of Wisconsin, Madison

Wendy C. Chi* University of Colorado, Boulder

Casey Cobb University of Connecticut

Arnold Danzig Arizona State University

Antonia Darder University of Illinois, UrbanaChampaign

Linda Darling-Hammond Stanford University

Chad d'Entremont Strategies for Children

John Diamond Harvard University

Tara Donahue Learning Point Associates

Sherman Dorn University of South Florida

Christopher Joseph Frey Bowling Green State University

Melissa Lynn Freeman* Adams State College

Amy Garrett Dikkers University of Minnesota

Gene V Glass Arizona State University

Ronald Glass University of California, Santa Cruz

Harvey Goldstein Bristol University

Jacob P. K. Gross Indiana University

Eric M. Haas WestEd

Kimberly Joy Howard* University of Southern California

Aimee Howley Ohio University

Craig Howley Ohio University

Steve Klees University of Maryland

Jaekyung Lee SUNY Buffalo
Christopher Lubienski University of Illinois, UrbanaChampaign

Sarah Lubienski University of Illinois, UrbanaChampaign

Samuel R. Lucas University of California, Berkeley

Maria Martinez-Coslo University of Texas, Arlington

William Mathis University of Colorado, Boulder

Tristan McCowan Institute of Education, London

Heinrich Mintrop University of California, Berkeley

Michele S. Moses University of Colorado, Boulder

Julianne Moss University of Melbourne

Sharon Nichols University of Texas, San Antonio

Noga O'Connor University of Iowa

João Paraskveva University of Massachusetts, Dartmouth

Laurence Parker University of Illinois, UrbanaChampaign

Susan L. Robertson Bristol University

John Rogers University of California, Los Angeles

A. G. Rud Purdue University

Felicia C. Sanders The Pennsylvania State University

Janelle Scott University of California, Berkeley

Kimberly Scott Arizona State University

Dorothy Shipps Baruch College/CUNY

Maria Teresa Tatto Michigan State University

Larisa Warhol University of Connecticut

Cally Waite Social Science Research Council

John Weathers University of Colorado, Colorado Springs

Kevin Welner University of Colorado, Boulder

Ed Wiley University of Colorado, Boulder

Terrence G. Wiley Arizona State University

John Willinsky Stanford University

Kyo Yamashiro University of California, Los Angeles

* Members of the New Scholars Board 


\section{archivos analíticos de políticas educativas consejo editorial}

Editor: Gustavo E. Fischman (Arizona State University)

Editores. Asociados Alejandro Canales (UNAM) y Jesús Romero Morante (Universidad de Cantabria)

Armando Alcántara Santuario Instituto de Investigaciones sobre la Universidad y la Educación, UNAM México

Claudio Almonacid Universidad Metropolitana de Ciencias de la Educación, Chile

Pilar Arnaiz Sánchez Universidad de Murcia, España

Xavier Besalú Costa Universitat de Girona, España Jose Joaquin Brunner Universidad Diego Portales, Chile

Damián Canales Sánchez Instituto Nacional para la Evaluación de la Educación, México

María Caridad García Universidad Católica del Norte, Chile

Raimundo Cuesta Fernández IES Fray Luis de León, España

Marco Antonio Delgado Fuentes Universidad Iberoamericana, México

Inés Dussel FLACSO, Argentina

Rafael Feito Alonso Universidad Complutense de Madrid, España

Pedro Flores Crespo Universidad Iberoamericana, México

Verónica García Martínez Universidad Juárez Autónoma de Tabasco, México

Francisco F. García Pérez Universidad de Sevilla, España

Edna Luna Serrano Universidad Autónoma de Baja California, México

Alma Maldonado Departamento de Investigaciones Educativas, Centro de Investigación y de Estudios Avanzados, México

Alejandro Márquez Jiménez Instituto de Investigaciones sobre la Universidad y la Educación, UNAM México

José Felipe Martínez Fernández University of California Los Angeles, USA
Fanni Muñoz Pontificia Universidad Católica de Perú

Imanol Ordorika Instituto de Investigaciones Economicas - UNAM, México

Maria Cristina Parra Sandoval Universidad de Zulia, Venezuela

Miguel A. Pereyra Universidad de Granada, España

Monica Pini Universidad Nacional de San Martín, Argentina

Paula Razquin UNESCO, Francia

Ignacio Rivas Flores Universidad de Málaga, España

Daniel Schugurensky Universidad de Toronto-Ontario Institute of Studies in Education, Canadá

Orlando Pulido Chaves Universidad Pedagógica Nacional, Colombia

José Gregorio Rodríguez Universidad Nacional de Colombia

Miriam Rodríguez Vargas Universidad Autónoma de Tamaulipas, México

Mario Rueda Beltrán Instituto de Investigaciones sobre la Universidad y la Educación, UNAM México

José Luis San Fabián Maroto Universidad de Oviedo, España

Yengny Marisol Silva Laya Universidad Iberoamericana, México

Aida Terrón Bañuelos Universidad de Oviedo, España

Jurjo Torres Santomé Universidad de la Coruña, España

Antoni Verger Planells University of Amsterdam, Holanda

Mario Yapu Universidad Para la Investigación Estratégica, Bolivia 


\section{arquivos analíticos de políticas educativas conselho editorial \\ Editor: Gustavo E. Fischman (Arizona State University) Editores Associados: Rosa Maria Bueno Fisher e Luis A. Gandin \\ (Universidade Federal do Rio Grande do Sul)}

Dalila Andrade de Oliveira Universidade Federal de Minas Gerais, Brasil

Paulo Carrano Universidade Federal Fluminense, Brasil

Alicia Maria Catalano de Bonamino Pontificia Universidade Católica-Rio, Brasil

Fabiana de Amorim Marcello Universidade Luterana do Brasil, Canoas, Brasil

Alexandre Fernandez Vaz Universidade Federal de Santa Catarina, Brasil

Gaudêncio Frigotto Universidade do Estado do Rio de Janeiro, Brasil

Alfredo M Gomes Universidade Federal de Pernambuco, Brasil

Petronilha Beatriz Gonçalves e Silva Universidade Federal de São Carlos, Brasil

Nadja Herman Pontificia Universidade Católica -Rio Grande do Sul, Brasil

José Machado Pais Instituto de Ciências Sociais da Universidade de Lisboa, Portugal

Wenceslao Machado de Oliveira Jr. Universidade Estadual de Campinas, Brasil
Jefferson Mainardes Universidade Estadual de Ponta Grossa, Brasil

Luciano Mendes de Faria Filho Universidade Federal de Minas Gerais, Brasil

Lia Raquel Moreira Oliveira Universidade do Minho, Portugal

Belmira Oliveira Bueno Universidade de São Paulo, Brasil

António Teodoro Universidade Lusófona, Portugal

Pia L. Wong California State University Sacramento, U.S.A

Sandra Regina Sales Universidade Federal Rural do Rio de Janeiro, Brasil

Elba Siqueira Sá Barreto_Fundação Carlos Chagas, Brasil

Manuela Terrasêca Universidade do Porto, Portugal

Robert Verhine Universidade Federal da Bahia, Brasil

Antônio A. S. Zuin Universidade Federal de São Carlos, Brasil 